\title{
EVALUASI MODEL EXPLORE-APPLY-PRESENT DENGAN ENGLISH AUDIOPEDIA UNTUK PEMBELAJARAN BAHASA INGGRIS SMP
}

\author{
Suparti \\ Balai Pengembangan Media Radio Pendidikan dan Kebudayaan (BPMRPK) \\ suparti@kemdikbud.go.id
}

\begin{abstract}
Abstrak
Pengembangan model Explore-Apply-Present (EAP) dengan English Audiopedia perlu dievaluasi untuk mendapatkan rekomendasi terkait degan pengambilan keputusan tentang keberlangsungan proyek yang sedang dikembangkan. Penelitian evaluatif ini dilaksanakan pada bulan Oktober-Desember 2019 dengan responden 30 guru Bahasa Inggris SMP dan 420 peserta didik SMP dari empat lokasi yaitu Tangerang, Bandung, Surakarta, dan Surabaya. Instrumen yang digunakan dalam penelitian ini yaitu angket, panduan wawancara, dan diskusi kelompok terfokus. Hasil evaluasi menunjukkan bahwa model EAP dapat dimanfaatkan sebagai alternatif khususnya dalam pembelajaran menyimak. Ditinjau dari tingkat kelayakan, English Audiopedia layak digunakan sebagai alternatif sumber belajar karena baik dari sisi materi, teknis maupun kemediaan telah memenuhi standar produksi dengan melibatkan ahli di bidangnya. Model ini layak untuk dikembangkan sebagai alternatif pembelajaran listening dan alternatif dalam memenuhi keterbatasan sumber belajar listening yang sering dikeluhkan guru. Namun model ini perlu diperbaiki baik dari sisi format sajian, konten, maupun kemasan agar lebih menarik dan tepat sasaran.
\end{abstract}

Kata Kunci: EAP, English Audiopedia, menyimak, evaluasi

\section{EVALUATION OF THE EXPLORE-APPLY-PRESENT MODEL WITH ENGLISH AUDIOPEDIA FOR ENGLISH LEARNING IN JUNIOR HIGH SCHOOLS}

\begin{abstract}
The development of the Explore-Apply-Present (EAP) model with English Audiopedia needs to be evaluated to obtain recommendations related to decision making regarding the sustainability of the project being developed. This evaluative research was conducted in October-December 2019 with 30 junior high school English teachers and 420 junior high school students as respondents taken from four locations, namely Tangerang, Bandung, Surakarta, and Surabaya. The instruments used in this study were questionnaires, interview guides, and focused group discussion. The results of the evaluation showed that the EAP model with a scientific approach can be used as an alternative in teaching listening. Judging from the feasibility level, English Audiopedia was suitable for use as an alternative source of learning English because both material and technical aspects have met the standards in the development and production process by involving experts in their fields. This model was feasible to be developed as an alternative to teaching listening and as an alternative in meeting the limitations of English audio resources that teachers often complained about. However, this model needs to be improved both in terms of presentation format, content, and packaging to make it more attractive and suitable with the users.
\end{abstract}

Keywords: EAP, English Audiopedia, listening, evaluation

\section{PENDAHULUAN}

Bahasa Inggris menempati posisi yang sangat penting di Indonesia sehingga tak mengherankan jika Bahasa Inggris telah dimasukkan dalam kurikulum SD sampai Perguruan Tinggi (PT) bahkan ditambah ditetapkan sebagai syarat masuk dan tamat di sejumlah PT dengan tes TOEFL. Meskipun demikian, dalam konteks pembelajaran di Indonesia, Bahasa Inggris masih diperlakukan sebagai salah satu cabang ilmu sebagaimana mata pelajaran lain. Bahasa Inggris bukan merupakan alat komunikasi dan masih menduduki sebagai bahasa asing atau English as a Foreign Language atau EFL (Panggabean, 2016). Jadi, meskipun secara teoritis menempati posisi yang sangat penting, penguasaan Bahasa Inggris orang maupun pelajar Indosesia relatif masih sangat rendah di bandingkan negara-negara lainnya misalnya Korea, Jepang, Malaysia atau Thailand.

Rendahnya kemampuan Bahasa Inggris orang Indonesia dinyatakan dalam laporan hasil survei yang dilakukan sebuah lembaga Bahasa Inggris internasional yang bernama English First (EF). Dari hasil survei English 
Proficiency Index (EPI) edisi ke-9 tahun 2019 yang dilakukan terhadap negara-negara di dunia, Indonesia menempati urutan ke-61 dari 100 negara yang disurvei mengenai kemahiran berBahasa Inggris. Dalam hal ini terjadi penurunan skor dari 51.58 di tahun 2018 menjadi 50.06 di tahun 2019. Posisi Indonesia ini juga berada di bawah negara Asia lainnya antara lain di bawah Filipina (60.04), Malaysia (58.55) dan Vietnam (51.57). Secara umum, kemahiran berBahasa Inggris orang Indonesia berada di bawah rata-rata kemampuan Bahasa Inggris kawasan Asia yang berada di angka 53.0 (EF, 2019).

Fakta hasil survei tersebut sejalan dengan apa yang terjadi di lapangan. Banyak pelajar di Indonesia yang tetap tidak bisa berbicara dalam Bahasa Inggris meskipun mereka telah belajar selama bertahun-tahun, setidaknya saat mereka duduk di bangku setingkat SMP dan SMA. Jangankan berbicara, mengungkapkan ide dalam Bahasa Inggris dan memahami teks sederhana saja pun masih banyak yang kesulitan. Demikian pula dengan kemampuan menyimak teks Bahasa Inggris khususnya teks otentik. Ada beberapa faktor yang mempengaruhi kegagalan dalam menguasai Bahasa Inggris antara lain karena Bahasa Inggris masih diperlakukan sebagai subjek berbasis pengetahuan, mempelajarinya secara pasif tanpa upaya gigih, memiliki motivasi yang salah misalnya sekedar mengejar nilai dan kelulusan saja, jarang digunakan untuk berkomunikasi, dan tidak pernah diperguankan di luar konteks (Pardede 2018).

Pengajaran Bahasa Inggris adalah pengajaran yang seyogyanya berfokus pada peningkatan kompetensi peserta didik untuk mampu menggunakan bahasa tersebut dalam mencapai tujuan komunikasi di berbagai konteks, baik lisan maupun tulis melalui pembelajaran berbasis teks, yang mengacu pada fungsi bahasa dan penggunaannya sebagai satu kesatuan makna baik lisan maupun tulis (Kemendikbud, 2016). Selain itu perlu diperhatikan bahwa mata pelajaran Bahasa Inggris memiliki karakteristik yang berbeda dengan mata pelajaran lain. Perbedaan ini terletak pada fungsi bahasa sebagai alat komunikasi. Hal ini mengindikasikan bahwa belajar Bahasa Inggris bukan saja belajar kosakata dan tataba hasa, tetapi belajar pula bagaimana menggunakan atau mengaplikasikan pengetahuan tersebut dalam kegiatan komunikasi (Depdiknas, 2006).

Merujuk pada pernyataan tersebut, seorang peserta didik belum bisa dikatakan menguasai dan mahir ber-Bahasa Inggris jika kemampuan berkomunikasi Bahasa Inggrisnya masih rendah, sungguh pun secara nilai hasilnya bagus. Oleh karena itu, peserta didik perlu meningkatkan kemampuan Bahasa Inggris secara seimbang karena dalam belajar bahasa, orang mengenal ada keterampilan reseptif dan produktif. Keterampilan reseptif meliputi keterampilan menyimak (listening) dan keterampilan membaca (reading), sedangkan keterampilan produktif meliputi keterampilan berbicara (speaking) dan keterampilan menulis (writing). Jadi, baik keterampilan reseptif maupun keterampilan produktif perlu dikembangkan. (Depdiknas, 2006).

Dalam pengajaran keterampilan berbahasa Inggris di Indonesia, menyimak (listening) merupakan salah satu keterampilan yang dianggap sulit namun terabaikan, bila dibandingkan dengan keterampilan berbahasa lainnya seperti berbicara, membaca dan menulis. Hal ini disebabkan karena dalam pengajaran bahasa Inggris di sekolah-sekolah guru cenderung meng-utamakan pengajaran keterampilan berbicara (speaking), membaca (reading) dan menulis (writing). Selain itu kondisi ini diperburuk dengan penilaian masyarakat yang beranggapan bahwa bila seseorang mampu berbicara dengan baik, maka hal tersebut merupakan cerminan bahwa orang tersebut juga mampu berkomunikasi dengan baik. Kemampuan untuk berbicara dengan baik merupakan komponen penting dalam kesuksesan berkomunikasi, namun kemampuan menyimak yang baik juga merupakan komponen yang penting dalam berkomunikasi. Di kalangan masyarakat terdapat anggapan bahwa kesuksesan 
seseorang dalam berkomunikasi ditentukan oleh kemampuannya dalam berbicara. Mereka terfokus pada suatu keyakinan bahwa seseorang yang belajar bahasa terutama bahasa asing dapat dilihat atau diukur dari kemampuannya berbicara, menulis dan membaca, yang secara langsung dapat diamati. Namun sangat jarang orang melihat bahwa kemampuan berbahasa seseorang sebenarnya juga ditentukan oleh kemam-puannya dalam memahami bahasa lisan (kemampuan listening).

Dari pernyataan tersebut, dalam proses pembelajaran Bahasa Inggris, pengembangan keempat aspek keterampilan berbahasa perlu dilakukan secara seimbang. Namun, dalam konteks pengajaran Bahasa Inggris di Indonesia, menyimak (listening) merupakan salah satu keterampilan yang dianggap sulit namun justru terabaikan bila dibandingkan dengan keterampilan berbahasa lainnya seperti berbicara, membaca dan menulis. Padahal kemampuan menyimak merupakan komponen sangat penting dalam berkomunikasi. Jadi, kemampuan berbahasa seseorang juga ditentukan oleh kemampuannya dalam memahami bahasa lisan atau kemampuan listening (Adnan, 2012).

Senada dengan hal itu, selama ini dalam konteks pembelajaran Bahasa Inggris, pembelajaran listening juga cenderung tidak maksimal bila dbandingkan dengan keterampilan berbahasa lainnya seperti berbicara, membaca dan menulis. Umumnya pengajaran keterampilan menyimak diajarkan guru dengan membacakan teks dalam Bahasa Inggris dan peserta didik diminta untuk mendengarkan. Guru mengulang membacakan teks tersebut sampai dua atau tiga kali, setelah itu peserta didik diminta menjawab pertanyaan yang diberikan guru (Sulastri, 2018). Cara ini bisa dikatakan kurang efektif dan kurang terstandar karena peserta didik sesungguhnya juga memerlukan pajanan (exposure) teks Bahasa Inggris lisan yang benar dan otentik agar mereka bisa memahami Bahasa Inggris sebagaimana yang diucapkan oleh penutur aslinya.
Berdasarkan hal tersebut, sebagai institusi yang salah satu tugas utamanya mengembangkan model dan format media audio pembelajaran, pada tahun 2019, Balai Pengembangan Media Radio Pendidikan dan Kebudayaan (BPMRPK) mengembangkan salah satu model pembelajaran Bahasa Inggris yaitu model EAP (Explore-Apply-Present) yang disertai dengan pengembangan media audio pembelajarannya yang bernama English Audiopedia. Selain itu, model ini juga dilengkapi dengan bahan penyerta yang dapat dicetak untuk mempermudah dan memaksimalkan pemanfaatannya. Sebagai media audio, English Audiopedia dikembangkan secara popular dengan gaya monolog lisan yang dibawakan oleh native speaker dengan tujuan meningkatkan kompetensi menyimak/listening. Materi dalam bahan belajar ini dikembangkan dengan mengacu pada kurikulum Bahasa Inggris 2013 dengan pendekatan model pembelajaran yang disederhanakan dari pendekatan saintifik/ scientific approach menjadi model yang lebih sederhana yang diberi nama model ExploreApply-Present/EAP (Suparti, dkk, 2019).

Pengembangan model EAP dengan English Audiopedia, pada dasarnya mengadopsi prosedur pengembangan model yang dikenal dengan nama model ADDIE yang merupakan akronim dari tahapan yang meliputi analysis, design, development, implementation, and evaluation. Analysis adalah proses untuk mengidentifikasi apa yang harus dipelajari. Design adalah proses menentukan bagaimana itu dipelajari dengan menentuan cetak biru/blue print dari rancangan yang akan dikembangkan. Development adalah proses memproduksi materi yang akan digunakan sedangkan implementation adalah proses bagaimana hasil perancangan dan produksi/pengembangan tersebut diterapkan/dimanfaatkan dalam konteks nyata di lapangan. Berikutnya adalah evalution yang hakikatnya merupakan proses yang terjadi di keseluruhan tahap/fase pengembangan, baik pada tahap di dalam tiap fasenya, fase di antaranya maupun fase setelah penerapan atau pemanfaatan (McGriff, 2000). 
Pada hakikatnya evaluasi adalah kegiatan untuk mengumpulkan informasi tentang bekerjasanya sesuatu yang selanjutnya dapat digunakan untuk menentukan alternatif yang tepat dalam mengambil sebuah keputusan/kebijakan (Arikunto \& Jabar, 2014). Jadi dengan adanya evaluasi seseorang dapat mengambil keputusan secara profesional berdasarkan analisis data yang dihasilkan, baik data kuantitatif maupun kualitatif.

Senada dengan hal itu, evaluasi dapat diartikan sebagai sebuah proses yang sistematis dan berkelanjutan untuk menentukan kualitas sesuatu berdasarkan pertimbangan dan kriteria tertentu dalam rangka mengambil suatu keputusan. Jadi dalam evaluasi ada proses mendeskripsikan, mengumpulkan dan menyajikan suatu informasi yang bermanfaat untuk pertimbangan dalam pengambilan keputusan. Informasi yang dihasilkan dalam proses evaluasi dapat pula dijadikan dasar untuk mengetahui taraf kemajuan, perkembangan, dan pencapaian tujuan, serta keefektifan suatu program baik pada tahap perencanaan, pelaksanaan maupun pengolahan hasil (Asrul, Ananda dan Rosita, 2014). Dengan demikian, evaluasi memiliki peranan penting dalam upaya perbaikan, mengetahui efektivitas dan efisiensi dari suau program ataupun model pembelajaran yang sedang dikembangkan, atau pun daam rangka pengambilan keputusan atau kebijakan.

Evaluasi sendiri pada dasarnya dilakukan untuk menjawab beberapa pertanyaan seperti: (1) apakah tujuan pembelajaran selaras dengan tujuan pengembangan program; (2) apakah rencana pembelajaran bahan ajar, media, dan penilaian, selaras dengan kebutuhan pembelajaran; (3) apakah perubahan perlu dilakukan pada desain untuk meningkatkan efektivitas; (4) apakah peserta didik memperoleh pengetahuan dan keterampilan yang dibutuhkan; (5) apakah peserta didik dapat mentransfer pembelajaran mereka sesuai dengan konteksnya (Calhoun, 2020). Pertanyaan-pertanyaan tersebut dapat digunakan untuk membantu dalam mengembangkan desain pembelajaran sesuai dengan kebutuhan dan konteksnya.

Salah satu model evaluasi yang dapat diterapkan dalam pengembangan sebuah program pembelajaran adalah evaluasi formatif dan sumatif. Evaluasi formatif digunakan untuk mendapatkan informasi yang bertujuan untuk memperbaiki suatu program. Evaluasi ini dilakukan pada saat penerapan atau implementasi program sedang berjalan. Sementara itu, evaluasi sumatif digunakan untuk menilai dan mmemutuskan apakah suatu program akan diteruskan atau dihentikan saja (Ananda, 2017).

Sebuah sumber lain menyebutkan bahwa evaluasi formatif dilakukan selama proses pengembangan untuk memberikan umpan balik yang menginformasikan sebuah proses. Sementara itu, evaluasi sumatif dilakukan pada akhir proses pengembangan untuk menentukan apakah apakah sebuah program telah mencapai hasil sesuai dengan tujuan yang telah ditetapkan. Secara mudah dapat dianalogikan dengan ungkapan, "ketika seorang koki mencicipi sup sebelum memberikan kepada pelanggan, itulah evaluasi formatif. Namun ketika para tamu/pelanggan mencicipi sup, itulah evaluasi sumatif." Jadi, evaluasi formatif terjadi selama proses pengembangan untuk mengevaluasi pembelajaran dan bahan/media pembelajaran untuk mendapatkan umpan balik yag mendorong dialkukannya revisi/perbaikan. Sehingga pengajaran akan lebih efektif dan efisien. Namun demikian, ketika evaluasi sumatif dan konfirmatif menunjukkan efek yang tidak diinginkan, maka hasilnya dapat digunakan sebagai alat evaluasi formatif untuk melakukan perbaikan (Calhoun, 2020).

Pendapat lain mengungkapkan bahwa evaluasi formatif diarahan untuk menyempurnaan sebuah proses sedangkan evaluasi sumatif diarahkan untuk memutuskan apakah sebuah program cukup efektif dan efisian ataukah justru sebaiknya yang pada akhirnya nanti menghasilkan rekomendasi terkait keberlanjutan sebuah program, apakah akan terus, berhenti, ataukah diteruskan dengan dilakukan perbaikan terlebih dahulu 
(Sukmadinata, 2005). Dalam konteks ini evaluasi formatif digunakan untuk menyempurnaan model dan format media audio pembelajaran sedangkan evaluasi sumatif digunakan untuk memutuskan apakah model dan format media yang telah dikembangkan tersebut efektif dan efisien dalam mencapai tujuan yang telah ditetapkan.

Penelitian evaluatif yang dilakukan penulis merupakan bagian dari proses dalam prosedur pengembangan model dan format media audio pembelajaran. Tujuan dari penelitian ini yaitu untuk mengetahui efektivitas model pembelajaran ExploreApply-Present (EAP) dengan English Audiopedia mengetahui efektivitas model EAP dengan English Audiopedia untuk pembelajaran Bahasa Inggris di SMP sehingga akan diperoleh rekomendasi terkait keberlangsungan model yang sedang dikembangkan.

Bagi lembaga BPMRPK, penelitian evaluatif ini bermanfaat dalam mengetahui kelemahan dan kelebihan model pembelajaran EAP maupun media English Audiopedia yang menyertainya agar dapat dilakukan perbaikan terkait model yang sedang dikembangkan. Selain itu, hasil penelitian ini juga bermanfaat dalam memberikan rekomendasi terkait pengambilan keputusan/kebijakan untuk keberlangsungan pengembangan model dan produksi program dalam skala yang lebih luas. Bagi pengembang desain pembelajaran, penelitian ini bermanfaat sebagai referensi terkait tahapan evaluasi dalam pengembangan sebuah model/media audio pembelajaran. Sementara bagi calon pengguna, rekomendasi hasil penelitian ini akan memberikan informasi yang bermanfaat untuk menentukan apakah model pembelajaran EAP dengan English Audiopedia ini layak digunakan dalam mendukung pembelajaran Bahasa Inggris khusunya untuk meningkatkan ketrampilan menyimak.

\section{METODE}

Sesuai dengan tujuan penelitian, jenis penelitian ini dikategorikan sebagai penelitian evaluasi. Penelitian evaluasi merupakan kegiatan penelitian untuk mengumpulkan data, menyajikan informasi yang akurat dan objektif mengenai implementasi program yang telah dikembangkan yaitu model pembelajaran Explore-Apply-Present (EAP) dengan English Audiopedia berdasarkan kriteria yang ditetapkan. Penelitian evaluatif ini menekankan pada evaluasi proses dengan menggunakan pendekatan sumatif yang dilaksanakan setelah proses implementasi atau penerapan program dilaksanakan. Selanjutnya, berdasarkan akurasi dan objektivitas informasi yang diperoleh dari hasil penelitian, selanjutnya dapat ditentukan nilai atau tingkat keberhasilan program, sehingga bermanfaat untuk pemecahan masalah yang dihadapi serta mempertimbangkan apakah program tersebut perlu dilanjutkan atau perlu dimodifikasi sebelum diteruskan.

Pendekatan yang digunakan dalam penelitian ini adalah pendekatan kuantitatif dan didukung dengan pendekatan kualitatif. Pendekatan kuantitatif digunakan untuk mendapatkan hasil evaluasi yang mendalam dan komprehensif, pendekatan ini digunakan untuk menangani data-data yang bersifat kuantitatif (angka). Sedangkan pendekatan kualitatif digunakan dengan didasarkan pada pertimbangan bahwa penelitian ini merupakan proses yang dilakukan melalui kajian terhadap kemampuan listening atau aktifitas para peserta didik yang terlibat di dalamnya.

Penelitian ini dilakukan pada bulan Oktober-Desember 2019 dengan mengambil populasi guru Bahasa Inggris dan peserta didik SMP dari empat lokasi yaitu Surabaya, Bandung, Tangerang, dan Yogyakarta. Sampel dalam penelitian ini melibatkan 30 orang guru dan 420 peserta didik SMP dari empat lokasi tersebut. Selain itu, penelitian ini juga melibatkan dosen Bahasa Inggris UNY sebagai expert judgement dan praktisi pendidikan/guru Bahasa Inggris yang dipilih berdasarkan kriteria tertentu. Selanjutnya terkait dengan obyek penelitian adalah model EAP sendiri dengan memanfaatkan English Audiopedia dengan judul "Save us, please" 
dan "Can you see my tail?" untuk jenjang SMP Kelas IX.

Jenis instrumen yang digunakan dalam penelitian ini adalah angket untuk guru dan peserta didik pedoman wawancara dan panduan diskusi terfokus. Angket guru meliputi angket sebelum dan sesudah penerapan sementara untuk angket peserta didik diambil setelah proses implementasi atau penerapan dilakukan. Angket sebelum penerapan digunakan untuk mengetahui pendekatan pembelajaran Bahasa Inggris yang dilaksanakan di sekolah, kelebihan dan kendala yang dihadapi dalam pembelajaran, dan media pembelajaran yang digunakan untuk mendukung kegiatan pembelajaran tersebut. Angket setelah penerapan disusun dengan tujuan untuk mengumpulkan data dan informasi tentang aspek-aspek yang berpengaruh terhadap penerapan model EAP dan efektivitas media audio English Audiopedia yang menyertainya.

Pedoman wawancara dilakukan dengan mengadakan komunikasi dengan subjek penelitian sehingga diperoleh data-data yang diperlukan terkait model EAP dengan English Audiopedia. Teknik wawancara mendalam ini diperoleh langsung dari subyek penelitian melalui serangkaian tanya jawab dengan guruguru Bahasa Inggris yang telah menerapkan model ini. Wawancara ini ditujukan untuk mengetahui pokok permasalahn dan memperoleh masukan serta memformulakan kembali model dan format EAP sesuai dengan hasil evaluasi dan kebutuhan di lapangan. Selanjutnya diskusi terfokus dengan melibatkan seorang dosen dan tiga guru Bahasa Inggris sebagai expert judgment. Diskusi terfokus ini bertujuan untuk meningkatkan kedalaman informasi yang diperoleh dan menyingkap berbagai aspek yang ditemukan agar dapat didefinisi dan diberikan penjelasan melalui diskusi dari berbagai perspektif sehingga dihasilkan justifikasi dan rekomendasi.

Data dan informasi yang diperoleh dari lapangan selanjutnya diolah atau dianalisis dengan menggunakan analisis secara kuantitatif dan deskriptif kualitatif. Teknik analisis data kuantitatif digunakan untuk menganalisis hasil angket dengan responden guru dan peserta didik sedangkan teknik analisis data deskriptif kuantitatif dipergunakan untuk menganalis hasil wawancara dan diskusi terfokus.

Sebelum evaluasi model EAP dengan English Audiopedia diterapkan, dilakukan persiapan di lapangan pada guru yang akan menerapkan/memanfaatkan program memalui serangkaian kegiatan bimbingan teknis dengan tujuan menginformasikan, mengarahkan, dan memberikan bekal dan pemahaman pada pendidik/guru dalam penerapan model pembelajaran EAP dengan English Audiopedia agar sesuai dengan tujuan pengembangan model yang telah ditetapkan.

\section{HASIL DAN PEMBAHASAN Hasil}

Pada bagian ini akan disajikan dan dideskripsikan data dan informasi yang diperoleh dari lapangan berdasarkan hasil instrumen, panduan wawancara, dan diskusi terfokus. Hal ini dimaksudkan untuk menjawab tujuan penelitian yaitu mengetahui efektivitas model pembelajaran Explore-Apply-Present (EAP) dengan English Audiopedia dan mengetahui dalam pembelajaran Bahasa Inggris di SMP. Deskripsi penyajian data dan informasi ini selanjutnya akan dianalisis dalam pembahasan hasil penelitian.

\section{Deskripsi Data Terkait Model EAP}

Berikut ini akan dideskripsikan data terkait hasil penerapan model EAP dari empat lokasi yaitu Tangerang, Bandung, Surakarta, dan Surabaya. Data yang disajikan pada bagian pertama ini menyangkut persepsi terkait model EAP dilihat dari sisi pendekatan pembelajaran Bahasa Inggris yang dilaksanakan di sekolah, kelebihan dan kendala yang dihadapi, dan media pembelajaran yang digunakan untuk mendukung kegiatan pembelajaran tersebut yang selanjutnya dikaitkan dengan model EAP yang sedang dikembangkan.

Dari Gambar 1 berikut, terlihat bahwa pendekatan saintifik mendominasi pilihan guru dalam hal pendekatan pembelajaran dimana 
47\% guru memilih pendekatan tersebut. Menurut pendapat guru, pendekatan saintifik mampu membuat peserta didik aktif dan berpikir kritis karena pembelajaran terpusat pada mereka dan menuntut mereka untuk berpikir ke tingkat tinggi. Selain ini pendekatan ini memungkinkan peserta didik untuk bereksplorasi dan terfokus pada kegiatan pembelajaran.

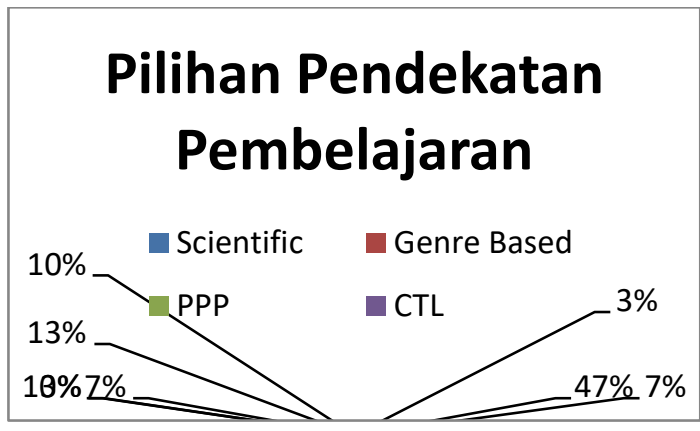

Gambar 1. Pilihan pendekatan pembelajaran

Terkait dengan sumber belajar yang digunakan dalam pembelajaran Bahasa Inggris, guru memanfaatkan buku paket pemerintah, buku pendamping lain, dan berusaha mengkreasikan materi dari bahanbahan yang ada di internet. Sementara itu, pada Gambar 2 terlihat bahwa dalam pembelajaran Bahasa Inggris khususnya listening, $43 \%$ guru belum pernah memanfaatkan media dalam pembelajaran listening, sedangkan 57\% pernah menerapkannya yaitu berupa berupa penggunaan lagu Bahasa Inggris dan beberapa materi yang dicari dari internet.

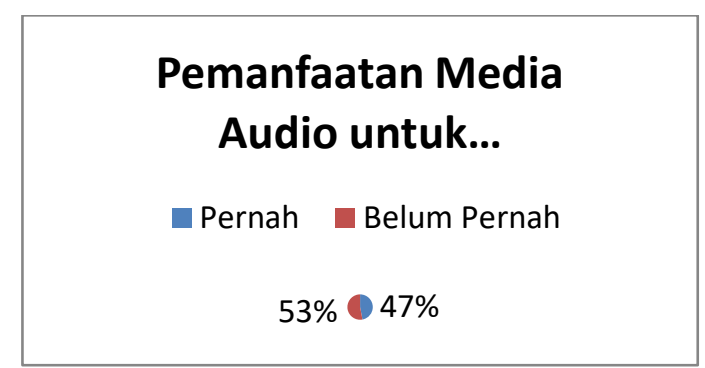

Gambar 2. Pemanfaatan MA Listening

Berdasarkan Gambar 3 terlihat bahwa $59 \%$ responden guru menyatakan sangat setuju, 29\% menyatakan setuju, sedangkan $12 \%$ menyatakan tidak setuju jika pendekatan EAP sejalan dengan pembelajaran aktif. Guru yang berpendapat tidak setuju menyatakan bahwa English Audiopedia masih cenderung ke model pembelajaran pasif. Peserta didik hanya mendengar lalu menjawan pertanyaan. Guru berharap media audio bahasa Inggris yang dihasilkan nantinya bisa variatif dan disesuaikan agar bisa lebih atraktif lagi dalam mendukung pembelajaran aktif.

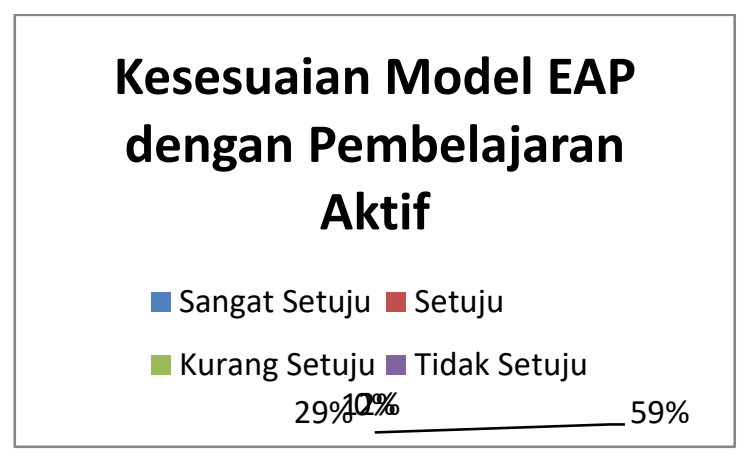

Gambar 3. Kesesuaian model EAP dengan pembelajaran aktif

Dari gambar 4 berikut terlihat bahwa $82 \%$ responden guru menyatakan sangat setuju dan $18 \%$ menyatakan setuju jika model EAP bisa/mudah diimplemetasikan dalam pembelajaran Bahasa Inggris di sekolah. Selain itu, sebagian responden guru juga mengusulkan agar model EAP dibuat lebih sederhana lagi dan materi-materi pembelajaran semua jenjang bisa segera diperbanyak dan disebarluaskan.

\section{Kemudahan Model EAP untuk Diimplemetasikan}

$$
\begin{aligned}
& \square \text { Sangat Setuju } \square \text { Setuju } \\
& \text { Kurang Setuju } \square \text { Tidak Setuju } \\
& 18 \% \% \frac{8 \%}{82 \%}
\end{aligned}
$$

Gambar 4. Kesesuaian model EAP untuk diimplementasikan

\section{Deskripsi Data Terkait English Audiopedia \\ Berikut ini akan dideskripsikan data terkait hasil pemanfaatan English Audiopedia yang menyertai pengembangan model EAP dari empat lokasi yaitu Tangerang, Bandung,}


Surakarta, dan Surabaya. Data yang disajikan pada bagian kedua ini menyangkut aspek materi dan teknis dari media Englsih Audiopedia yang dikembangkan. Data akan disajikan secara berdampingan antara responden guru dan peserta didik.

Dari grafik di Gambar 5 terbaca bahwa $52 \%$ responden guru dan 53\% responden peserta didik menyatakan sangat, $46 \%$ dan $41 \%$ menyatakan setuju dan hanya $2 \%$ dan $6 \%$ yang menyatakan tidak setuju jika materi dalam media audio atau bahan belajar English Audiopedia sesaui denga materi yang dibelajarkan di sekolah. Responden juga menghendaki agar materi dalam English Audiopedia bisa dibuat lebih variatif, misalnya mendeskripsikan tentang suatu pekerjaan, tempat yang menarik, biografi orang/tokoh terkenal, dan fenomena/materi lain yang dapat memperkaya pengetahuan siswa.

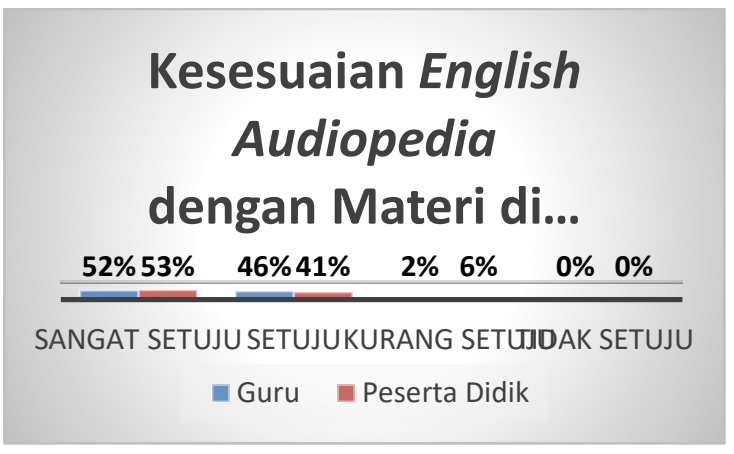

Gambar 5. Kesesuaian materi English Audiopedia

Berikutnya akan disajikan data mengenai apakah English Audiopedia tepat untuk memperkaya pengetahuan peserta didik. Berdasarkan Gambar 6 berikut, terlihat bahwa $88 \%$ responden guru dan $57 \%$ responden peserta didik menyatakan sangat setuju, $12 \%$ dan $41 \%$ menyatakan setuju jika materi dalam English Audiopedia dapat digunakan untuk memperkaya pengetahuan yang dapat mendukung pembelajaran di bidang lainnya.

Namun menurut pendapat sebagian responden, prototipa yang diberikan dengan materi jenis teks report tentang hewan simpanse dan tokek kurang memotivasi karena masih monoton. Materi diharapkan bisa disesuaikan dengan perkembangan zaman agar lebih menantang dan memabngkitkan rasa ingin tahu.

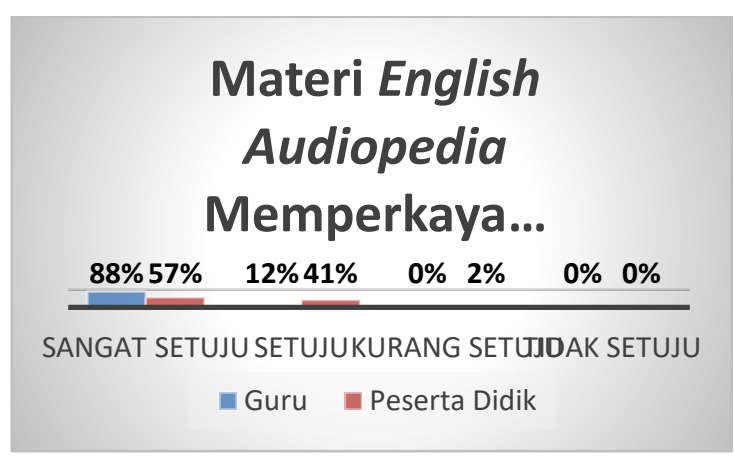

Gambar 6. Materi English Audiopedia

Memperkaya Pengetahuan

Berdasarkan Gambar 7 berikut, terlihat bahwa $24 \%$ responden guru, 29\% responden peserta didik menyatakan sangat setuju, $76 \%$ setuju jika tingkat kesulitan materi dalam English Audiopedia sesuai dengan tingkat kemampuan berbahasa Inggris peserta didik. Namun demikian, ada yang berpendapat jika materi ini terlalu mudah dipahami karena peserta didik sudah punya cukup pengetahuan. Selain itu, materi pembahasan kurang up to date. Namun ada juga yang berpendapat jika tingkat kesulitan materi sudah sesuai dengan kemampuan peserta didik yang masih terbatas.

\section{Tingkat Kesulitan Materi} English Audiopedia sesuai kemampuan Peserta Didik

$24 \% 29 \% \quad 76 \% 56 \% \quad 0 \% \quad 14 \% \quad 0 \% \quad 0 \%$

SANGAT SETUJU SETUJUKURANG SETUTIDAK SETUJU

- Guru $\square$ Peserta Didik

Gambar 6. Kesesuaian tingkat kesulitan materi English Audiopedia

Berdasarkan Gambar 7 berikut, 82\% responden guru, $40 \%$ responden peserta didik menyatakan sangat setuju, $18 \%$ guru, $54 \%$ peserta didik setuju jika kosa kata dalam program English Audiopedia bermanfaat membantu peserta didik memahami materi yang diberikan. Namun, menurut pendapat responden guru, kosakata yang diperdengarkan 
untuk kata-kata sulit perlu diperbanyak sehingga khasanah perbendaharaan kosakata peserta didik bertambah. Dengan demikian mereka akan lebih mudah memahami teks yang akan diperdengarkan. Selain itu, kosa kata sulit perlu ditambahkan lagi karena kemampuan peserta didik dalam memahami kata/vocabulary Bahasa Inggris bervariasi, ada yang sudah cukup baik, namun ada pula yang masih sangat terbatas. Menurut pendapat responden guru, kosakata akan lebih bagus lagi jika didukung oleh gambar yang sekaligus bisa digunakan guru untuk bercerita sesuai dengan konteks. Selain itu, penggunaan kosakata juga bisa dimasukkan ke dalam konteks kalimat sehingga menjadi lebih jelas. Responden peserta didik juga mengusulkan agar vocabulary bisa lebih paham dan semangat belajar Bahasa Inggris lebih meningkat.

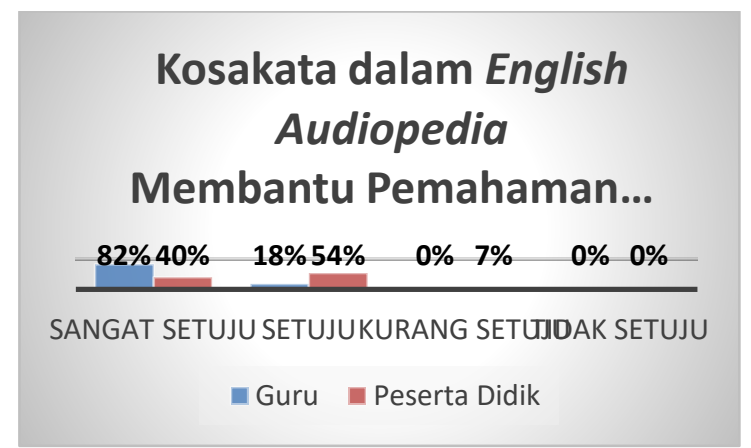

Gambar 7. Penyajian kosakata dalam English Audiopedia

Berdasarkan Gambar 8 terlihat bahwa $82 \%$ responden guru, $41 \%$ responden peserta didik menyatakan sangat setuju, $18 \%$ responden guru, $56 \%$ responden siswa setuju jika latihan soal yang diberikan dapat menambah pemahaman dan sesuai dengan materi yang diberikan di sekolah. Namun, ada masukan dari responden jika latihan soal hendaknya bisa lebih mengaktifkan peserta didik karena Selain itu, untuk pertanyaan terkait listening comprehension kurang menyeluruh sehingga perlu ditambah soal baik terkiat factual/inferential questions, kata rujukan atau makna kata untuk memandu peserta didik lebih memahami teks.

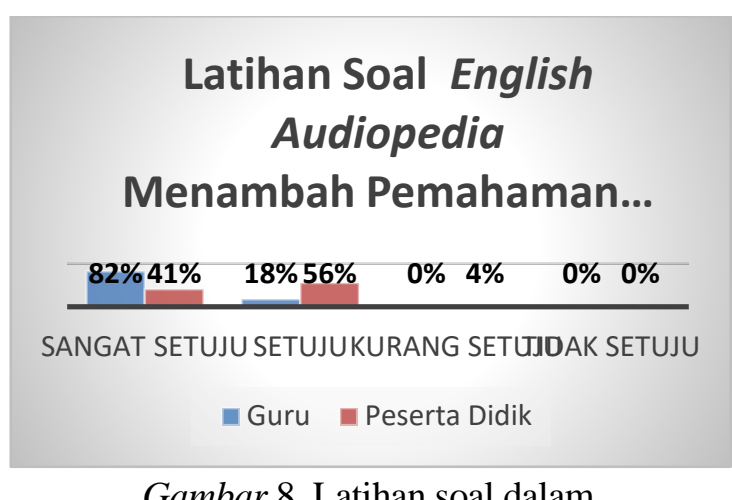

Gambar 8. Latihan soal dalam English Audiopedia

Pada bagian berikut ini akan disajikan deskripsi data terkait sisi teknis atau aspek kemediaan mengenai English Audiopedia. Hal yang disajikan meliputi kualitas program, penggunaan bahasa, durasi program, dan kemudahan pemanfaatan.

Dari segi kualitas teknis, berdasarkan Gambat 9 terbaca bahwa $76 \%$ responden guru dan $52 \%$ responden siswa, menyatakan sangat setuju, $24 \%$ dan $42 \%$ menyatakan setuju dengan penilaian terhadap kualitas English Audiopedia yang dikategorikan baik. Menurut pendapat mereka, English Audiopedia yang disajikan sangat bagus dari segi kualitas suara, intonasi dan keterlibatan native speaker, tetapi untuk menyajikan di kelas, perlu diberikan semacam apersepsi untuk menyiapkan peserta didik memasuki pembelajaran inti.

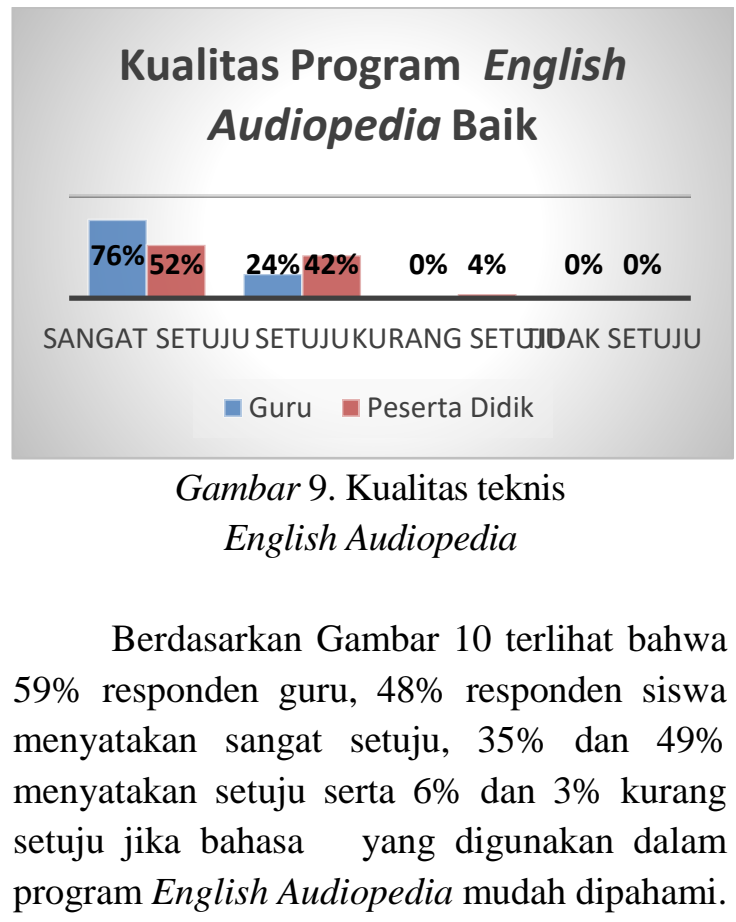


Namun, ada pula responden guru yang menganjurkan agar penggunaan bahasa Inggris dibuat pula dengan penggunaan Bahasa Inggris penuh, sehingga penjelasan materi dalam Bahasa Indonesia bisa diambil alih oleh guru. Hal senada juga diungkapkan oleh beberapa responden peserta didik. Namun, ada pula responden peserta didik yang menyatakan bahwa porsi penggunaan bahasa Indonesia dirasa membantu mereka memahami materi karena kemampuan bahasa Inggris yang masih terbatas.

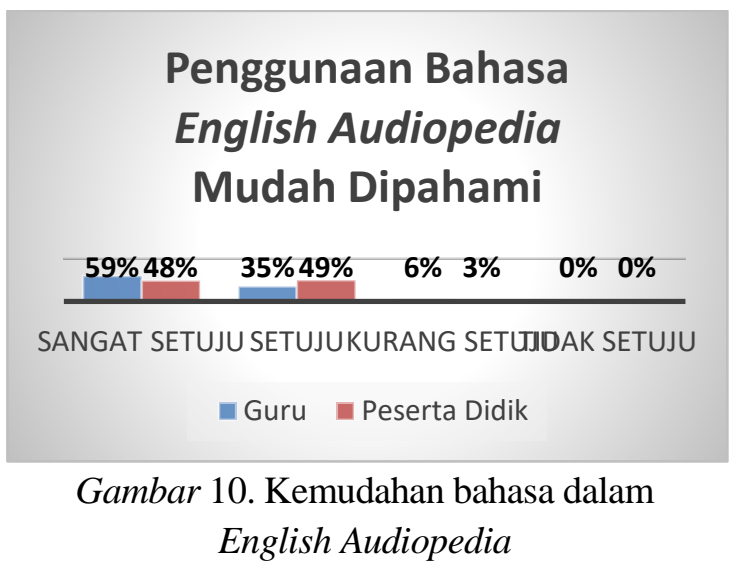

Dari segi durasi program berdasarkan Gambar 11, 29\% responden guru, 46\% responden peserta didik menyatakan sangat setuju, $71 \%$ dan $47 \%$ menyatakan setuju dengan ketepatan durasi program yang ditampilkan. Secara umum track 1 berdurasi sekitar 4-5 menit sedangkan latihan soal dan pembahasan pada track 2 berdurasi sekitar 910 menit.

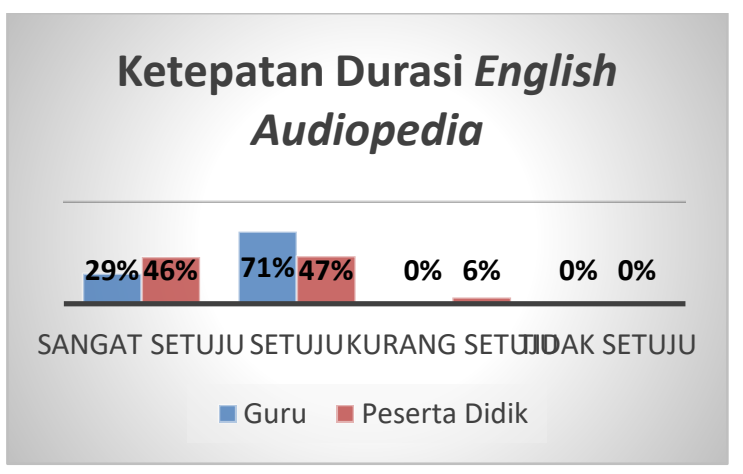

Gambar 11. Ketepatan durasi

English Audiopedia
Berdasarkan Gambar 12 berikut terbaca bahwa $82 \%$ responden guru dan $46 \%$ responden siswa menyatakan sangat setuju, $18 \%$ dan $51 \%$ menyatakan setuju, menyatakan bahwa dari sisi teknis pemanfaatan English Audiopedia, mudah digunakan karena dalam format mp3 yang sederhana dan disertai dengan panduan pemanfaatan yang dikemas dalam format cetak maupun soft filenya. Namun alangkah baiknya jika jika jumlah program yang diproduksi sudah kemas dapat dikemas lebih menarik menjadi semacam podcast.

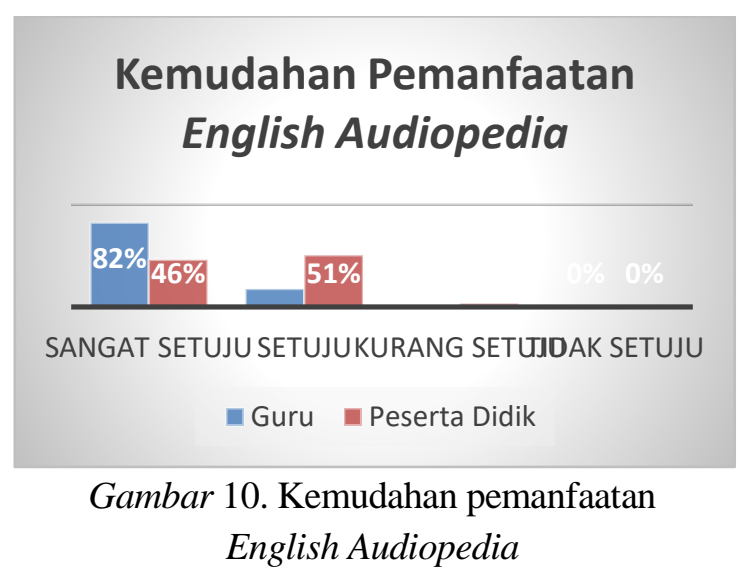

\section{Pembahasan}

Pembahasan pada bagian ini akan dibagi dalam dua bagian. Bagian pertama membahas tentang interpretasi data terkait dengan model Explore-Apply-Present (EAP) dan bagian kedua mengenai interpretasi terkait pengembangan media audio pembelajaran yang menyertainya yaitu English Audiopedia. Data yang diolah dianalisis dan diinterpretasi dengan merujukpada studi dan dokumen yang ada serta melalui diskusi yang mendalam dengan ahli materi, ahli pembelajaran, dan guru selaku praktisi di lapangan.

Terkait pendekatan pembelajaran yang dipilih, pendekatan saintifik merupakan pendekatan pembelajaran yang menjadi pilihan pada sebagaian besar responden guru. Hal ini sejalan dengan pernyataan yang mengatakan bahwa metode yang direkomendasikan untuk diterapkan dalam pembelajaran adalah metode saintifik yang diperkaya dengan inquiry learning, pendekatan berbasis masalah dan pendekatan berbasis proyek (Priyono, 2014). Merujuk pada 
hal tersebut, meskipun pendekatan saintifik adalah pendekatan yag disaranakan, namun guru bisa melakukan adaptasi dan penyesuaian dengan tetap mengacu pada pendekatan pembelajaran yang sifatnya pembelajaran aktif, salah satu dengan model EAP dengan English Audiopedia.

Model EAP dengan English Audiopedia ini pada dasarnya merupakan model pembelajaran Bahasa Inggris yang dikembangkan dengan mengacu pada pendekatan model pembelajaran saintifik yang disederhanakan. Model ini dilengkapi dengan pengembanagn bahan belajar listening yang dinamakan English Audiopedia. Bahan belajar pendukung tersebut dikembangkan secara popular dengan gaya monolog lisan dan dibawakan oleh native speaker. Materi dalam bahan belajar ini dikembangkan dengan mengacu pada kurikulum bahasa Inggris 2013. Pendekatan pembelajaran dengan model EAP tidak menjadi persoalan karena pendekatan pembelajaran apa pun dipandang fleksibel untuk digunakan guru dengan tetap memperhatikan situasi, kondisi, dan gaya belajar masing-masing peserta didik. Model EAP yang diterapkan pada dasarnya sudah sesuai dan sejalan dengan pendekatan saintifik.

Pendekatan saintifik pada hakikatnya adalah pembelajaran yang terdiri atas kegiatan mengamati yaitu (1) mengidentifikasi hal-hal yang ingin atau perlu diketahui, (2) menanya atau merumuskan pertanyaan, (3) mengumpulkan informasi dengan satu atau lebih teknik, (4) menalar atau mengasosiasi yaitu menggunakan data atau informasi untuk menjawab pertanyaan atau menarik kesimpulan, dan (5) mengomunikasikan jawaban atau kesimpulan. Langkah-langkah tersebut dapat dilanjutkan dengan kegiatan mencipta (Kemendikbud, 2016).

Merujuk pada hal tersebut, jika pendekatan model EAP disejajarkan dengan pendekatan saintifik, dapat digambarkan dalam Tabel 1 berikut.

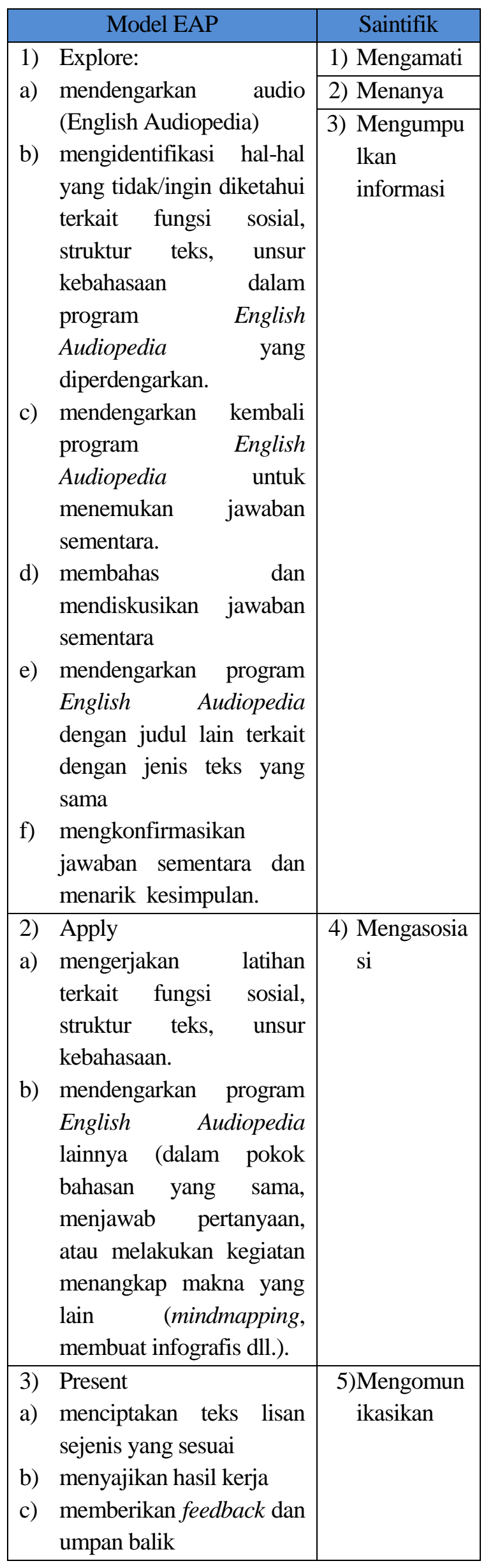


Terkait dengan materi dalam model EAP dengan English Audiopedia, maka materi ini sangat relevan dengan materi di sekolah dan kurikulum 2013. Pemetaan materi EAP pun sudah dilakukan sehingga setelah prototipa model selesai dibuat, pemetaan materi yang ada dapat dikembangkan dan diproduksi menjadi bahan belajar audio yang melengkapi model EAP, baik itu diperuntukkan bagi kelas VII, VIII, IX SMP maupun tidak tertutup kemungkinan dikembangkan untuk jenjang SMA/SMK.

Bagian kedua akan menganalisis dan menginterretasi data terkait dengan efektifitas bahan belajar English Audiopedia ditinjau dari sisi materi maupun teknis kemediaan.

Secara umum, responden menyatakan bahwa materi yang dikembangkan dalam English Audiopedia akan dapat memperkaya pengetahuan layaknya sebuah materi ensiklopedia pada umumnya. Namun, English Audiopedia memiliki kelebihan karena secara materi sesuai dengan kurikulum, dikemas secara popular dengan gaya bahasa lisan yang akrab serta dapat pula digunakan untuk mendukung materi pelajaran lainnya. Hal ini relevan dengan penjalasan dalam silabus Bahasa Inggris yang menyatakan bahwa pembelajaran Bahasa Inggris berbasis teks mendukung pembelajaran pada mata pelajaran lain dalam kurikulum. Misalnya, pembelajaran teks deskriptif akan mengembangkan kemampuan peserta didik antara lain pada mata pelajaran Seni Budaya untuk mempromosikan wisata. Selain itu, pembelajaran jenis teks lain akan membantu peserta didik dalam memperluas wawasan keilmuannya tentang materi dalam mata pelajaran lain dalam skala internasional (Kemendikbud, 2016). Jadi tidak terlepas juga, pembelajaran tentang teks laporan/report akan mendukung dalam mapel IPA, pembelajaran teks naratif akan mendukung pembelajaran Bahasa Indonesia, dll.

Terkait dengan kosakata yang ditampilkan, penyajian kosakata sedikit banyak akan berpengaruh pada tingkat pemahaman peserta didik dalam memahami materi yang disajikan dan akan mempengaruhi pula pada tingkat kesulitan teksnya. Hal ini sesuai dengan peneltian yang dilakukan pada siswa Kelas X SMK N 2 Depok, Sawangan yang menyatakan bahwa penguasaan kosakata mempengaruhi hasil kemampuan pemahaman membaca teks persuasif bahasa Inggris peserta didik. Kurangnya pengetahuan tentang kosa kata akan menimbulkan kesenjangan dalam menginterpretasikan makna. Padahal, penguasaan kosakata merupakan inti dalam memahami makna bacaan atau teks (Santosa, 2017). Jadi penguasaan terkait kosa perlu ditampilkans ebagai saran untuk membangun konteks dan mempermudah pemahaman. Demikian juga pemberian latihan soal merupakan hal penting yang sejaan untuk mengetahui tingkat pemahaman peserta didik.

Dari sisi teknis kualitas audio yang dihasilkan dalam bahan belajar English Audio juga sudah terstandar dengan baik karena mengikuti prosedur standar yang ditetapkan dalam proses produksi di BPMRPK. Demikian juga dari sisi pengisi suara sudah melewati proses audisi sehingga pengisi suara memiliki standar terkait kualitas suara dan juga pemainan karakter sesuai dengan jenis naskah yang dibawakan termasuk juga penggunaan bahasa yang digunakan telah melalui proses pengkajian dan preview sehingga terjaga kualitas dan standarnya.

Terkait dengan durasi audio bahan belajar Engslish Audiopedia yang berkisar antara track 1 berdurasi sekitar 4-5 menit sedangkan latihan soal dan pembahasan pada track 2 berdurasi sekitar 9-10 menit bisa katakana cukup ideal. Hal ini didukung oleh pendapat yang mengatakan bahwa durasi ideal untuk mendengarkans ebuah program audio adalah sekitar sepanjang sebuah lagu. Ada pula yang berpendapat sekitar 10-15 menit, namun durasi lebih dari 15 menit dirasa terlalu lama (Lucy \& Clark, 2010). Namun demikian, keidealan durasi sbuah program ditentukan pula oleh faktor usia, format program yang disampaikan maupun gaya belajar seseorang.

Hal berikutnya yaitu terkait sisi teknis pemanfaatan dimana bahan belajar English Audiopedia yang dikemas dalam bentuk podcast yang dilengkapi dengan bahan penyerta pendukung dalam versi cetak maupun soft file sangat diperlukan untuk memaksimalkan pemanfaatannya. Hal ini sejalan dengan pendapat yang menyatakan bahwa podcast dapat meningkatkan pemahaman peserta didik dalam 
menyimak dan memberikan peluang menarik untuk mengekspos percakapan otentik yang dapat membantu meningkatkan pendengaran, pemahaman dan kosa kata. Selain itu, peserta didik akan mendapatkan kepercayaan pada kemampuan mereka untuk dapat memahami bahasa secara keseluruhan (Apriani, 2020). Dalam konteks ini, pemanfaatan podcast sangat cocok untuk pembelajaran bahasa, termasuk Bahasa Inggris.

Hal terakhir yang dibahas yaitu menyangkut kemudahan akses. Secara umum, prototipa English Audiopedia yang dikemas dalam bentuk podcast berformat mp3 dengan bahan penyerta soft file dalam versi pdf relatif mudah diakses, apalagi di era digital seperti sekarang ini. Jika di tahapan berikutnya bahan belajar English Audiopedia ini diproduksi secara luas untuk memenuhi kebutuhan pembelajaran secara lengkap untuk tiap jenjangnya, bahan belajar ini perlu dikemas dalam bentuk semacam podcast atau semacam e-pembelajaran yang daapt diakses melalui web maupun media berbasis internet.

Secara umum, model EAP dengan English Audiopedia ini layak dikembangkan untuk mendukung pembelajaran Bahasa Inggris karena keeftifannya dalam berbagai hal, baik dari sisi pembelajaran, konten materi maupun aspek teknis kemediaan. Namun demikian, ada beberapa hal yang perlu diperbaiki terkait pengembangan dan produksi dari model yang sedang dikembangkan tersebut. Pertama terkait pendekatan model EAP dengan English Audiopedia perlu disesuaikan agar lebih bisa mendukung pembelajaran aktif. Kedua, topik materi dibuat lebih up to date, mengandung pengetahuan baru/sesuatu yang bermanfaat bagi peserta didik dan bisa mendukung pembelajaran di bidang studi/mata pelajaran lain. Ketiga jumlah kata dalam teks monolog lisanyang ditampilkan perlu ditingkatkan dengan tingkat common words sekitar $80 \%$ dan jumlah kata berkisar 200-250 kata dari jumlah kata sebelumnya yaitu sekitar 180-200 kata. Jadi peserta didik diharapkan masih dapat menangkap maksud teks yang disampaikan. Keempat, mengingat bahwa sebagian responden mengangkap bahwa soal perlu dieksplorasi lebih jauh untuk meningkatkan pemahaman, latihan soal perlu dibuat bertingkat dengan memperhatikan tahapan pembelajaran dalam EAP (Explore-Apply-Present) dan perlu disesuaikan jenis soal untuk masing-masing tahap dalam EAP.

\section{PENUTUP}

Secara umum tingkat kelayakan model EAP denggan English Audiopedia layak dilanjutkan sebagai salah satu model pembelajaran Bahasa Inggris berbasis audio. Model EAP dikatakan baik dan relevan untuk digunakan sebagai alternatif metode pembelajaran khususnya untuk meningkatkan ekterampilan menyimak atau listening. Hal ini karena model EAP sesuai dengan pendekatan saintifik sebagaimana disarnkan dalam Kurikulum 2013. Hanya saja untuk lebih mengaktifkan peserta didik dalam kegiatan pembelajaran, perlu disusun langkah-langkah khusus yang didukung dengan perbaikan dari format bahan belajar English Audiopedia yang menyertainya.

Hal kedua yaitu terkait dengan tingkat kelayakan bahan belajar yang menyertai model EAP, yaitu English Audiopedia. Secara umum, bahan belajar ini layak dimanfaatkan karena sangat relevan dengan konten pembelajaran dan materi Bahasa Inggris yang diajarkan di sekolah dan dapat digunakan untuk meningkatkan keterampilan menyimak yang selama ini terabaikan karena keterbatasan sumber belajar yang relevan. Secara kualitas, bahan belajar ini sudah baik, baik dari sisi kualitas audio maupun kebenaran materi karena telah memenuhi standar dala pengembangan yang telah ditetapkan BPMRPK dan memenuhi standar kelayakan baik dinyataan oleh ahli materi, ahli media, maupun praktisi pendidikan/guru sebagai calon pengguna. Demikian pula dari sisi teknis maupun kemudahan akses. Namun demikian, format sajian maupun konten bahan belajar English Audiopedia perlu disesuaikan lagi dengan mengacu pada rekomendasi hasil penelitian yang telah dihasilkan. 


\section{DAFTAR PUSTAKA}

Adnan, A. (2012). Pengajaran Menyimak Bahasa Inggris:Masalah dan Solusinya. Lingua Didaktika, Jurnal Bahasa dan Pembelajaran, 6(1):1 DOI 10.24036/ld.v6il.2549.

Ananda, R. \&. (2017). Pengantar Evaluasi ProgramPendidikan. Medan: Perdana Publishing.

Apriani, O. D. (2020). Podcast sebagai Media Pembelajaran Jarak Jauh. Retrieved Occtober 13, 2020, from https://www.researchgate.net/publicatio n/341250765_Podcast_sebagai_Media_ Pembelajaran_Jarak_Jauh_20_Jurnal/li nk/5eb55d67a6fdcc1f1dc8b4ce/downlo ad.

Arikunto, S. \&. (2014). Evaluasi Program Pendidikan. Jakarta: PT Bumi Aksara.

Asrul, A. R. (2015, September). Evaluasi Pembelajaran. Retrieved October 9, 2020, from https://core.ac.uk/download/pdf/530372 63.pdf.

Calhoun, C. S. (2020). Instructional Design Evaluation. In J. K. (Eds.), Design for Learning: Principles, Processes, and Praxis (pp. 432-438). https://edtechbooks.org/id.

Cheryl Calhoun, S. S. (n.d.). Instructional Design Evaluation. In J. K.Mc.

Clark, L. T. (2010). Educational Design of Short, Audio Podcast, the Teacher and Student Experience. Australasian Journal of Educaional Technology Vol 26 No 3, 2010, p 386-399.

Depdiknas. (2006). Panduan Pengembangan Silabus Mata Pelajaran Bahasa Inggris untuk Sekolah Menengah Pertama. Jakarta: Departemen Pendidikan dan Kebudayaan.

EF. (2019). EF English Proficiency Index. Retrieved October 9, 2020, from https://www.ef.com/wwen/epi/.

Kemendikbud. (2016). Panduan Pembelajaran untuk Sekolah Menengah Pertama. Jakarta: Kementerian Pendidikan dan Kebudayaan.
Kemendikbud. (2016). Silabus Mata Pelajaran Sekolah Menengah Pertama/Madrasah Tsanawiyah (SMP/MTs) Mata Pelajaran Bahasa Inggris. Jakarta: Kementerian Pendidikan dan Kebudayaan.

McGriff, S. J. (2000). Instructional System Design (ISD) Using the ADDIE Model. Retrieved October 9, 2020, from https://www.lib.purdue.edu/sites/default /files/directory/butler38/ADDIE.pdf.

Panggabean, H. (2016, January 1). https://www.researchgate.net/publicati on/313160996_URGENSI_DAN_POSI SI_BAHASA_INGGRIS_DI_INDONESI $A$. Retrieved October 9, 2020, from Urgensi dan Posisi Bahasa Inggris di Indonesia: www.researchgate.net

Pardede, P. (2018, November 27). Mengapa Banyak Siswa Gagal Belajar Bahasa Asing? . Retrieved October 9, 2020, from

https://eeduki.com/2018/11/27/mengap a-banyak-siswa-gagal-belajar-bahasaasing/.

Priyono, J. (2014). English Language Teaching Steps Based on the Scientific Method. Yogyakarta: Yogyakarta State University.

Santosa, P. P. (2017). Pengaruh Penguasaan Kosakata terhadap Kemampuan Membaca Teks Persuasif Bahasa Inggris Siswa Kelas X SMKN 2 Depok. DEIKSIS, Vol. 09 No.02, Mei 2017, hal. 170-181.

Sukmadinata, N. S. (2005). Metode Penelitian Pendidikan. Bandung: Program Pasasarjana UPI dan PT Remaja Rosdakarya.

Suparti, d. (2019). Laporan Rancangan Model EAP dengan English Audiopedia untuk Pembelajaran Bahasa Inggris . Yogyakarta: Balai Pengembangan Media Radio Pendidikan dan Kebudayaan. 